\title{
Comparative Effects of Oral and Injectable Bisphosphonates in Primary Human Gingival Fibroblasts
}

\author{
OCTAVIA IULIA BALEAN ${ }^{1}$, ALIN DANIEL FLOARE ${ }^{1}$, ROXANNE FOCHT ${ }^{1}$, DANIELA JUMANCA ${ }^{1}$, DORINA CORICOVAC $2 *$, \\ IULIA PINZARU ${ }^{2}$, ATENA GALUSCAN ${ }^{2 *}$, DOINA CHIORAN ${ }^{1}$, ADELINA CHEVERESAN ${ }^{3 *}$, ANGELA CODRUTA PODARIU ${ }^{2}$ \\ ${ }^{1}$ Victor Babes University of Medicine and Pharmacy Timisoara, Faculty of Dental Medicine, $2^{\text {nd }}$ Eftimie Murgu Sq, 300041, \\ Timisoara, Romania \\ ${ }^{2}$ Victor Babes University of Medicine and Pharmacy Timisoara, Faculty of Pharmacy, $2^{\text {nd }}$ Eftimie Murgu Sq, 300041, Timisoara, \\ Romania \\ ${ }^{3}$ Victor Babes University of Medicine and Pharmacy Timisoara, Faculty of Medicine, $2^{\text {nd }}$ Eftimie Murgu Sq, 300041, Timisoara, \\ Romania
}

Bisphosphonates are effective antiresorptive agents frequently used in the treatment of different bone disorders, as osteoporosis, Paget's disease and tumours that cause osteolysis. A major concern related to bisphosphonates therapy is represented by osteonecrosis of jaw, a serious, debilitating, and mostly, a therapyresistant disease, reported as a frequent side effect of bisphosphonates. The present study was aimed to assess and compare the effect of four commercially available bisphosphonates, very frequently used as oral (Fosamax - $F$ and Actonel - $A$ ) and injectable (Ossica - $O$ and Zoledronic acid - Z) therapy on primary human gingival fibroblasts - HGF viability. Alamar blue cell viability assay was performed to assess the effect of test compounds $(1.5 ; 2.5 ; 5$ and $10 \mu \mathrm{M})$ on gingival fibroblasts viability after a $24 \mathrm{~h}$ interval. In these experimental conditions, injectable bisphosphonates ( $O$ and $Z$ ) proved to be safe for HGF cells, whereas oral compounds $(F$ and $A)$ were cytotoxic even at low concentrations.

Keywords: bisphosphonates, primary human gingival fibroblasts, cell viability, cell morphology.

Bisphosphonates are a class of pharmaceutics applied as treatment for several bone disorders and cancers, as: Paget's disease, osteoporosis, multiple myeloma and hypercalcemia of malignancy, that act by suppressing osteoclast differentiation, impairing its activity and leading to early apoptosis. Their activity on osteoclast is also related to adverse events as damaged bone healing and remodeling processes that have as consequence an augmented risk of developing osteonecrosis of jaw, a serious and debilitating condition, in patients subjected to surgical dental procedures as extraction or implant placement [1$6]$. There were described two different classes of bisphosphonates: non-nitrogen and nitrogen containing (risedronate, alendronate, ibandonic acid and zoledronic acid -Figure 1) bisphosphonates, that present a disparate mechanism of action, as follows: non-nitrogen compounds are taken up by the osteoclast and metabolized to adenosine triphosphate analogues with noxious effects that induce osteoclast apoptosis or cell death, whereas nitrogen containing bisphosphonates are interiorized by osteoclasts during resorption process and impair the mevalonate pathway (involved in the synthesis of cholesterol) leading to suppression of bone resorption [7].

Since more than fifteen years ago, there were raised notable concerns regarding the liaison between the use of bisphosphonates and the increased risk to develop osteonecrosis of the jaw after invasive dental procedures [8]. A considerable number of studies were conceived to find strategies for dental management of patients at risk to develop osteonecrosis of the jaw following antiresorptive (bisphosphonates) and antiangiogenic compounds use [ 1 , 8-13], still, there are no effective therapeutic alternatives to reverse bisphosphonates noxious effects, and to find an appropriate prevention/treatment method for osteonecrosis of the jaw is rather challenging [14].

The present study was subjected to assess and compare the impact of orally (sodium risedronate -Actonel - $A$ and alendronate -Fosamax $-F$ ) versus intravenously (ibandronic acid -Ossica -O and zoledronic acid- Z) administered bisphosphonates on human primary gingival fibroblasts (HGF).

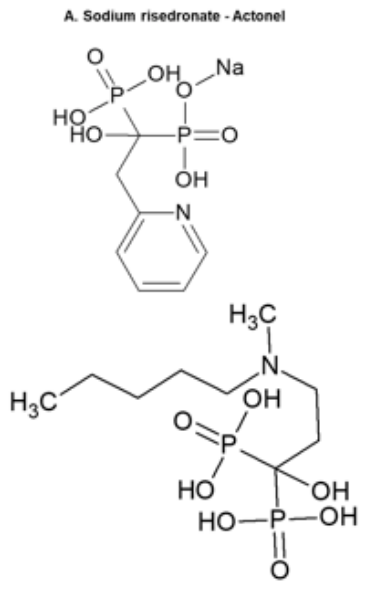

c. Ibandronic acid - Ossica<smiles>NCCCCCC(O)(OP(=O)(O)O)P(=O)(O)O</smiles><smiles>O=P(O)(O)C(Cn1ccnc1)(P(=O)(O)O)P(=O)(O)O</smiles>

Fig.1 Chemical structures of oral and injectable bisphosphonates tested: A. Sodium risedronate -Actonel; B. Sodium alendronate -Fosamax; C. Ibandronic acid Ossica and D. Zoledronic acid. The structures were obtained using $\mathrm{ACD} / \mathrm{ChemSketch}$ software. 


\section{Experimental part}

Materials and methods

Cell line

The cell line used in the present study was human primary gingival fibroblast - HGF (ATCC $®$ PCS-201-018 ${ }^{\mathrm{TM}}$ ) purchased from ATCC (American Type Cell Collection) and received as frozen vial. These cells are adherent, bipolar and refractile, present a spindle-shape and were obtained from a Caucasian female.

\section{Reagents}

The culture specific medium - Fibroblast Basal Medium (ATCC PCS-201-030), and Fibroblast growth kit-low serum (ATCC PCS-201-041) were acquired from ATCC, whereas the other reagents used, as: trypsin -EDTA solution, PBS (phosphate saline buffer), Trypan blue, DMSO (dimethyl sulfoxide), Alamar blue (resazurin sodium salt) were bought from Sigma Aldrich (Germany) and Thermo Fisher Scientific (USA). The test compounds from the class of bisphosphonates: Actonel (risedronic acid -75 mg tablets, Actavis, Islanda), Fosamax (Alendronate sodium -70 mg tablets, Merck Sharp \&Dohme, Romania), Ossica (ibandronic acid $-1 \mathrm{mg} / \mathrm{mL}$ solution for i.v administration, Gedeon Richter, Hungary) and Zoledronic acid (Actavis -4 $\mathrm{mg} / 5 \mathrm{~mL}$ solution for parenteral use), were prepared as follows: Actonel and Fosamax were dissolved in DMSO, obtaining stock solutions of $10 \mathrm{mM}$, and Ossica and Zoledronic acid were diluted in culture medium.

\section{Cell culture}

During the experiment, the cells were grown in specific media - Fibroblast Basal Medium (ATCC PCS-201-030), supplemented with Fibroblast grow th kit-low serum (ATCC PCS-201-041). HGF cells were maintained in a humidified incubator provided with $5 \% \mathrm{CO}_{2}$ at $37^{\circ} \mathrm{C}$. The cells were numbered using a cell counting device - Countess ${ }^{\mathrm{TM}}$ ॥ Automated Cell Counter (Thermo Fisher Scientific, USA), in the presence of Trypan blue.

\section{Cell viability assessment}

To verify the potential toxicity of the test compounds on human primary gingival fibroblasts - HGF it was applied Alamar blue assay. In brief, HGF cells were seeded in 96wells plates (1x104 cells/well/ $200 \mu / L)$ and let to grow until the appropriate confluence was reached ( 24 - $48 \mathrm{~h}$ ) [15]. Different concentrations (1.5; 2.5; 5 and $10 \mu \mathrm{M})$ of the test compounds (Actonel - A; Fosamax - F; Ossica - 0 , Zoledronic acid - Z) were added in fresh culture medium and maintained for $24 \mathrm{~h}$ in contact with HGF cells. After 24 $h$, it was added $20 \mu \mathrm{L}$ of Alamar blue, incubated for $3 \mathrm{~h}$ at $37^{\circ} \mathrm{C}$ and measured the absorbance values at 570 and 600 $\mathrm{nm}$ by the means of $\mathrm{xMark}^{\mathrm{TM}}$ Microplate Spectrophotometer (Biorad).

\section{Cell morphology}

The effects of test compounds $(A, F, O$ and $Z) \pm$ ozone saline solution on cells morphology were assessed by taking pictures before addition of test compounds and after the stimulation period ( $24 \mathrm{~h}$ ). The pictures were acquired by using the Olympus IX73 inverted microscope provided with DP 74 camera photo and documented with the CellSens V1.15 software (Olympus, Tokyo, Japan).

\section{Statistical analysis}

The results obtained were expressed as means $\pm S D$, and the difference between means was compared by oneway ANOVA, using the post-hoc Tukey's and Dunnett's multiple comparison tests (GraphPad Prism v. 6.0 Software,
SUA). The difference between groups was considered statistically significant if $p<0.05$.

\section{Results and discussions}

Bisphosphonates are synthetic analogues of pyrophosphates known to strongly bind to hydroxyapatite, a mineral from bone structure and modifybone resorption by decreasing bone metabolism and remodeling processes [8]. The side effects of bisphosphonates include irritation of the oesophagus, dysphagia, migraines, intestinal obstruction, joint and bone pain, but most importantly osteonecrosis of the jaws - a main dental adverse event $[3,5,11,12]$. Osteonecrosis of the jaw has become a major concern in the field of dentistry, since the risk of development to patients under the treatment with these agents that suffer invasive dental procedures is quite elevated and treating this kind of patients requires a complex management of the pathology. The most cases of osteonecrosis of jaw were recorded after administration of orally bisphosphonate -alendronate (the most frequently used worldwide) [2].

Taking into consideration that the category of patients that use bisphosphonates therapy becomes wider day by day (approximatively 75 million people are affected by osteoporosis in Europe, U.S. and J apan) [16], it is important to know the impact of these compounds in the organism, especially, since this kind of medication is for long-term.

In this study, it was verified and compared the effect of several types of bisphosphonates (Fosamax - F, Actonel A, Ossica - $O$ and Zoledronic acid - Z) on human primary gingival fibroblasts -HGF viability and morphology after a $24 \mathrm{~h}$ stimulation.

\section{Bisphosphonates decrease human primary gingival fibroblasts - HGF viability}

Stimulation for $24 \mathrm{~h}$ of HGF cells with different compounds from the bisphosphonates family led to distinct results regarding the percentage of viable cells, as follows: $Z$ and $O$ (Figure 2A) had no toxic effects on cells viability, moreover a stimulatory effect was noticed; in the case of Fosamax -F (Figure 2B) it was observed a dose-dependent toxicity, the lowest percentage of viable cells being recorded at $10 \mu \mathrm{M}$ (67.47 \% viable cells), and Actonel -A (fig. 2B) proved to be toxic even at the lowest concentrations tested ( 1.5 and $2.5 \mu \mathrm{M}: 77.93 \%$ and $79.33 \%$ ), percentage of viable cells that was close to the ones calculated for the highest concentration (5 and $10 \mu \mathrm{M}$ : 72.37 and $71.99 \%$ ).

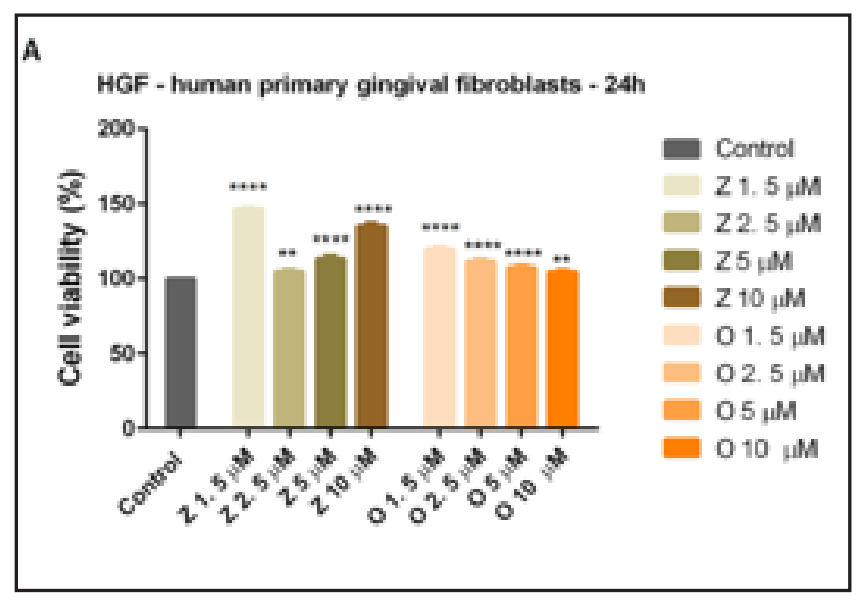




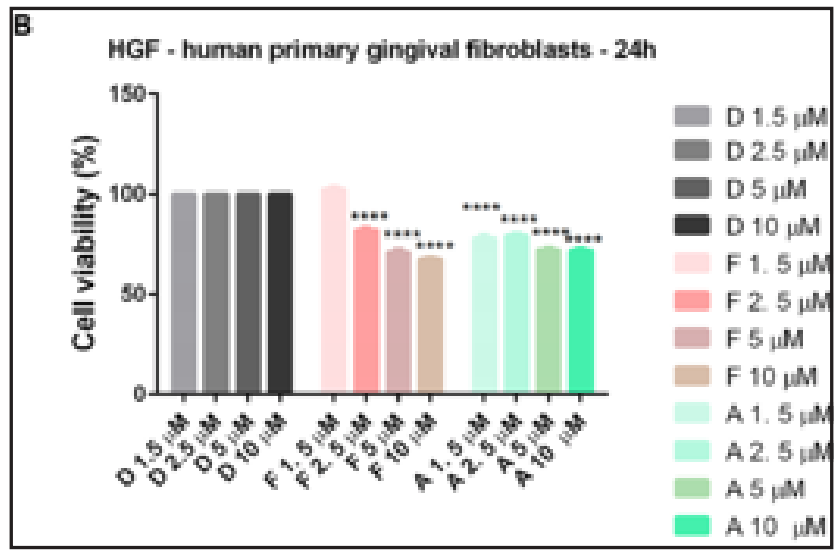

Fig. 2. In vitro viability evaluation of Zoledronic acid -Z, Ossica -0, Fosamax - F and Actonel -A (1.5, 2.5, 5 and $10 \mu \mathrm{M})$ on HGF -human primary gingival fibroblasts at $24 \mathrm{~h}$ post-stimulation by Alamar blue assay. The results are expressed as cell viability percentage (\%) normalized to control (for Z and 0 - stimulated cells) and to DMSO (for $F$ and A-stimulated cells). The data represent the mean values $\pm \mathrm{SD}$ of three independent experiments. One-way ANOVA analysis was applied to determine the statistical differences in rapport with control/DMSO followed by Dunnett's multiple comparisons posttest (** $p<0.01$ and $* * * * p<0.0001)$.

Bisphosphonates impair human primary gingival fibroblasts - HGF morphology

Since the viability results indicated signs of toxicity after test compounds stimulation ( $F$ and $A$ ), it was verified if there were induced some changes in cells morphology. DMSO was used as vehicle for Actonel and Fosamax. As it can be seen in Figure 3, DMSO-stimulated cells present similar characteristics as control (unstimulated) cells, spindle-shape, bipolar, adherence to the plate, what indicates no toxicity signs induced by different concentrations of DMSO.
Fosamax - F stimulation induced several slight changes of HGF cells shape, changes that become more evident with increasing the concentration (Figure 4). Most of the cells kept their spindle shape and their adherence was not affected, still there were also noticed some cells that were round and floating, and cells debris was also present (mainly at 5 and $10 \mu \mathrm{M}$ ), data that are in line with cell viability results.

Similar results as the ones described for Fosamax $-\mathrm{F}$ were observed in the cells stimulated with Actonel -A (Figure 5), with the difference that changes in cells shape (round cells), their adherence and the presence of cell debris appeared even at the lowest concentration (1.5uM).

In the case of cells stimulated with Zoledronic acid -Z (Figure 6) and Ossica - 0 (Figure 7), it was observed a higher confluence of the cells that presented similar shapes with control cells (spindle shape with a high adherence to the plate), data that are in agreement with cell viability findings (Figure 2A).

Human primary gingival fibroblasts were selected for this study based on the following considerations: (i) these cells are the main constituents of the gingival connective tissue and the most abundant residents of oral mucosa; (ii) play key roles in scarless wound healing process by releasing multiple growth factors (transforming growth factor beta - TGF-Beta, connective tissue growth factor CTGF, and basic fibroblast growth factor - bFGF); and iii) primary cells offer more reliable data as compare to immortalized cell lines [17, 18]. In addition, previous studies proved that primary human gingival fibroblasts are valuable and reliable in vitro models for screening toxicity/ cytocompatibility of dental materials $[17,19,20]$.

Our results showed that $F$ and $A$ become cytotoxic even at low concentrations as $1.5 \mu \mathrm{M}$ (Figure 2B) and also cells morphology was altered (Figures 4 and 5), whereas 0 and $Z$ had no cytotoxic effects at the concentrations tested $(1.5 ; 2.5 ; 5$ and $10 \mu \mathrm{M}$ ) (Figure 2A). The cytotoxic effect of

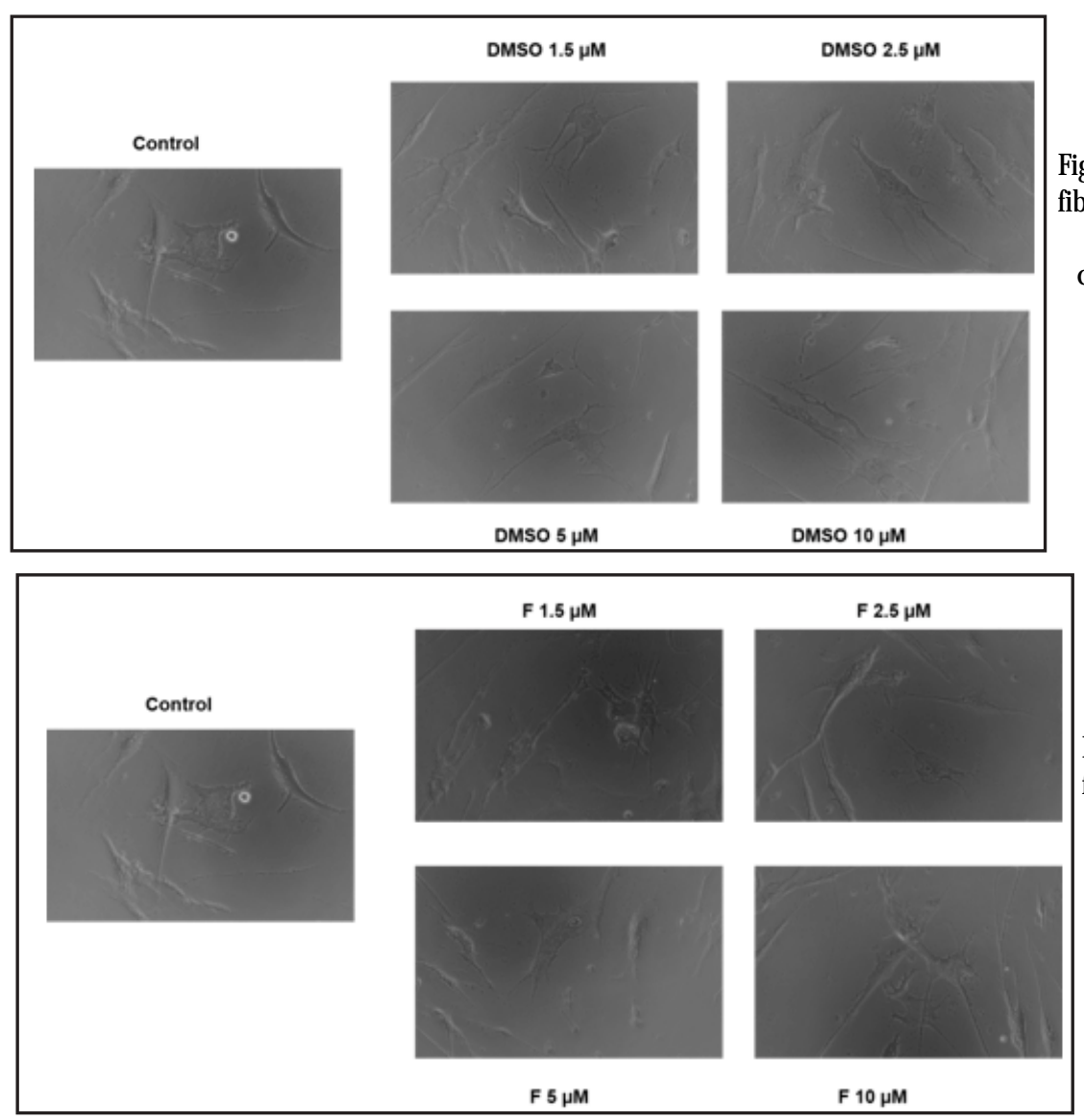

Fig.3 The aspect of HGF - human primary gingival fibroblasts in culture: Control -unstimulated cells and cells stimulated with different concentrations of DMSO $(1.5 ; 2.5 ; 5$ and $10 \mu \mathrm{M})$ for $24 \mathrm{~h}$. Pictures were taken using the $20 \mathrm{x}$ objective.

Fig. 4 The aspect of HGF -human primary gingival fibroblasts in culture: Control -unstimulated cells and cells stimulated with different concentrations of Fosamax - $F(1.5 ; 2.5 ; 5$ and 10 $\mu \mathrm{M})$ for $24 \mathrm{~h}$. Pictures were taken using the $20 \mathrm{x}$ objective. 


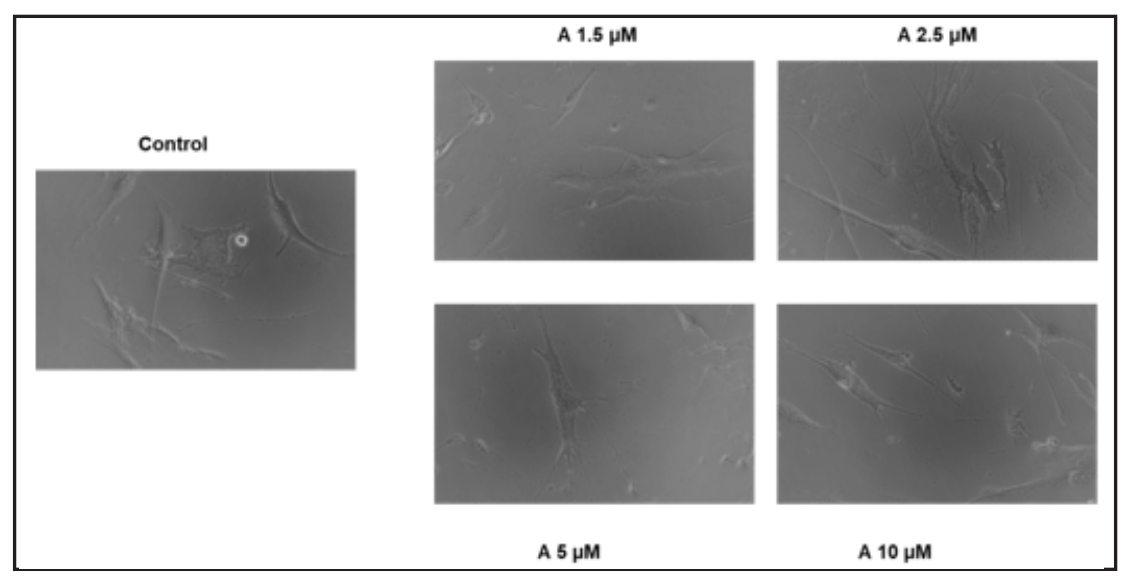

Fig.5 The aspect of HGF -human primary gingival fibroblasts in culture: Control unstimulated cells and cells stimulated with different concentrations of Actonel -A (1.5; 2.5;

5 and $10 \mu \mathrm{M}$ ) for $24 \mathrm{~h}$. Pictures were taken using the $20 x$ objective.

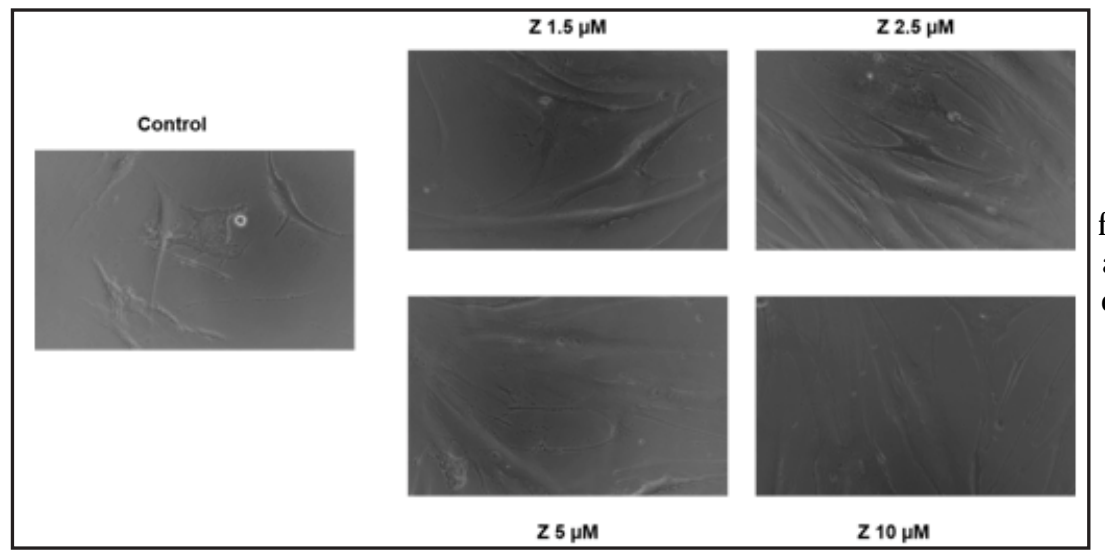

Fig. 6 The aspect of HGF -human primary gingival fibroblasts in culture: Control - unstimulated cells and cells stimulated with different concentrations of Zoledronic acid - Z (1.5; 2.5; 5 and $10 \mu \mathrm{M})$ for 24 h. Pictures were taken using the $20 x$ objective.

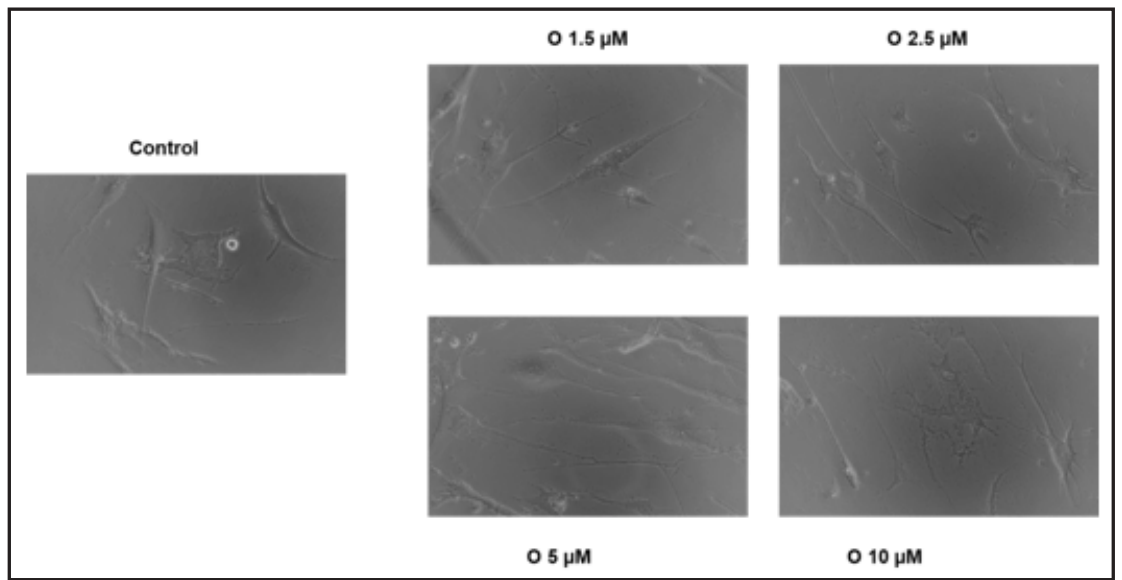

Fig.7. The aspect of HGF -human primary gingival fibroblasts in culture: Control unstimulated cells and cells stimulated with different concentrations of Ossica - 0 (1.5; 2.5; 5 and $10 \mu \mathrm{M})$ for $24 \mathrm{~h}$. Pictures were taken using the $20 x$ objective.

alendronate $-\mathrm{F}$ on human primary gingival fibroblasts was also shown by other groups of research [21-23], data that are in agreement with these results. Stimulation of human stem cells derived from the gingiva with risedronate in the range of $1-10 \mu \mathrm{M}$ led to changes in cells morphology and a reduced viability [24], findings that confirm our results.

An in vitro study developed on human umbilical cord vein endothelial cells (HUVEC), human gingival fibroblasts (HGF), human osteogenic cells (HHOB-c) and human oral keratinocytes (HOK) stimulated with $50 \mu \mathrm{M}$ ibandronate, pamidronate or zoledronate for $24 \mathrm{~h}$ showed that bisphosphonates used reduced all cells viability [25]. The results obtained in the present study showed that $Z$ (zoledronic acid) and 0 (ibandronic acid) are not cytotoxic for primary gingival fibroblasts at concentrations $\leq 10 \mu \mathrm{M}$.

Another study conducted by Soydan et al. [22] demonstrated the toxic effects of Alendronate (Fosamax) and PAM on human gingival fibroblasts, characterized by significant changes in the apoptotic and proliferative indices leading to an in vitro faulty epithelisation of the oral mucosa. The apoptotic index of the PAM group was significantly higher than the alendronate group for all concentrations, especially at $24 \mathrm{~h}$ of incubation $(p<0.05)$. The decrease in the proliferation index was similar for both drugs, however, after $72 \mathrm{~h}$ of incubation, the decrease in the PAM group proliferation index was significantly higher $(p<0.05)$. The change of these indices is an important factor in the management of delayed healing of the oral mucosa, secondary to surgery in patients under bisphosphonate treatment, and is a problem that reduces the success rate of healing in cases of bisphosphonateinduced maxillary osteonecrosis [26, 27].

\section{Conclusions}

In the view of all these findings, it could be stated that oral bisphosphonates - Fosamax and Actonel exert a concentration-dependent toxicity on human primary gingival fibroblasts by decreasing the percentage of viable cells and modifying cells morphology. In contrast, injectable bisphosphonates - Zoledronic acid and Ossica did not affect the viability or HGF cells morphology. 


\section{References}

1. MALDEN, N., BELTES, C., LOPES, V. Br Dent J ., 206, nr. 2, 2009, p. 93.

2. KALRA, S., JAIN, V. J Oral Biol Craniofac Res., 3, nr. 1, 2013, p. 25.

3. KUHL, S., WALTER, C., ACHAM, S., PFEFFER, R., LAMBRECHT, J., T. Oral Oncology., 48, nr. 10, 2012, p. 938.

4. COSKUN BENLIDAYI, I., GUZEL, R. ISRN Rheumatology, 2013, p. 1.

5. WATTS, N., B., DIAB, D., L. J Clin Endocrinol Metab., 95, nr. 4, 2010, p. 1555.

6. COLEMAN, R., E., MCCLOSKEY, E., V. Bone., 49, nr. 1, 2011, p. 71.

7. WANG, H., L., WEBER, D., MCCAULEY, L., K. J Periodontol., 78, nr. 3, 2007, p. 584.

8. DI FEDE, O., PANZARELLA, V., MAUCERI, R., FUSCO, V., BEDOGNI, A., LO MUZIO, L., SIPMO ONJ BOARD, CAMPISI, G. Biomed Res Int., 2018, 2018, p. 2684924.

9. KHAN, A., A., MORRISON, A., HANLEY, D., A., et al. J Bone Miner Res., 30, nr. 1, 2015, p.3.

10. COELLO-SUANZES, J., A., ROLLON-UGALDE, V., CASTAÑOSEIQUER, A., LLEDO-VILLAR, E., HERCE-LOPEZ, J., INFANTE-COSSIO,

P., ROLLON-MAYORDOMO, A. Oral Dis., 24, nr. 6, 2018, p. 1029.

11. POZZI, S., RAJE, N. The Oncologist., 16, nr. 5, 2011, p. 651.

12. ABRAHAMSEN, B. Calcif Tissue Int., 86, 2010, p. 421.

13. CORLAN, I.V., CHEVERESAN, A., BERCEANU VADUVA, D., NICA, C., FAUR, A., RUMEL, R.C., POPOVICl, R.A. Rev. Chim.(Bucharest), 69, no. 10, 2018, p. 2891.

14. ROSELLA, D., PAPI, P., GIARDINO, R., CICALINI, E., PICCOLI, L., POMPA, G. J Int Soc Prev Community Dent., 6, nr. 2, 2016, p. 97.

15. TALPOS, S., HAJAJ , T., TIMOFTE, C., RIVIS, M., STREIAN, F., POPA, M., et al. Mat. Plast., 55, no.1, 2018, p. 38.

16.*** Global Osteoporosis Treatment Market 2017-2025: Bisphosphonates, Parathyroid Hormone Therapy, Calcitonin, SERM and Rank Ligand Inhibitors. https://www.prnewswire.com/news- releases/global-osteoporosis-treatment-market-2017-2025-bisphosphonates-parathyroid-hormone-therapy-calcitonin-serm-andrank-ligand-inhibitors-300594031.html

17. SOARES, A., S., L., S., SCELZA, M., Z., SPOLADORE, J., et al. J Appl Oral Sci., 26, 2018, p. e20160594.

18. EGUSA, H., OKITA, K., KAYASHIMA, H., et al. PLoS One., 5, nr. 9, 2010, p. el2743.

19. PHAM, M., H., HAUGEN, H., J., RINNA, A., ELLINGSEN, J., E., RESELAND, J., E. J Tissue Eng., 10, 2019, p. 2041731419828950.

20. HERRAEZ-GALINDO, C., RIZO-GORRITA, M., LUNA-OLIVA, I., SERRERA-FIGALLO, M., Á., CASTILLO-OYAGÜE, R., TORRES-LAGARES, D. Polymers (Basel)., 11, nr. 4, 2019, p. 744.

21. ACIL, Y., MOLLER, B., NIEHOFF, P., RACHKO, K., GASSLING, V., WILTFANG, J., SIMON, M., J.J Craniomaxillofac Surg., 40, nr. 8, 2012, p. e229.

22. SOYDAN, S., S., ARAZ, K., SENEL, F., V., YURTCU, E., HELVACIOGLU, F., DAGDEVIREN, A., TEKINDAL, M., A., SAHIN, F. Hum Exp Toxicol., 34, nr. 11, 2015, p. 1073.

23. ACIL, Y., ARNDT, M., L., GULSES, A., WIEKER, H., NAUJ OKAT, $H_{.}$, AYNA, M., WILTFANG, J. J Craniomaxillofac Surg., 46, nr. 4, 2018, p. 538.

24. KIM, B., B., KO, Y., PARK, J., B. Biomed Rep., 3, nr. 6, 2015, p. 845. 25. WALTER, C., PABST, A., M., ZIEBART, T. Biomed Rep., 3, nr. 1, 2015, p. 14.

26. TIWARI, S., AVINASH, A., KATIYAR, S., AARTHI IYER, A., JAIN, S. The Saudi J ournal for Dental Research., 8, nr. 1-2, 2017, p. 105.

27. AKDENIZ, S., S., BEYLER, E., KORKMAZ, Y., YURTCU, E., ATES, U., ARAZ, K., SAHIN, F., I., TORUN, O., Y. Clin Oral Investig., 22, nr. 2, 2018, p. 867.

$\overline{\text { Manuscript received:02.06.2019 }}$ 